\title{
Presentation of solitary caecal diverticulitum imitating acute appendicitis
}

\author{
Ramesh Reddy, ${ }^{1}$ Ishaan Maitra, ${ }^{1}$ Paul Turner ${ }^{2}$
}

${ }^{1}$ General Surgery, Preston, UK ${ }^{2}$ Department of Upper GI Surgery, North West Deanery, Preston, UK

\section{Correspondence to}

Ishaan Maitra,

ishaan.maitra@googlemail.com

\section{DESCRIPTION}

Caecal diverticula are rare phenomena in the Western world especially among the Caucasian cohort. ${ }^{1}$ The incidence in Europe is $1-2 \%$ compared with $43-50 \%$ within Eastern Asia. ${ }^{1}$ In most situations, the presentation is similar to appendicitis offering an interesting diagnostic dilemma.

A 50-year-old athletic woman with no medical or surgical history presented with a 1-day history of constant abdominal pain. She initially developed central abdominal pain which migrated to the right iliac fossa. She felt nauseous but had no vomiting or urinary symptoms.

On examination, she had no fever, her pulse was $46 \mathrm{bpm}$ and blood pressure 96/52 (observations consistent with her hobby of fell running). There was no respiratory compromise. Abdominal examination revealed localised tenderness and guarding in the right iliac fossa. Her preoperative bloods were normal, and a presumptive clinical diagnosis of acute appendicitis was made. She had no preoperative radiological investigations performed as the suspicion of acute appendicitis was high.

On exploration a normal appendix was found with a solitary caecal inflamed diverticulum. She underwent a caecal diverticulectomy and appendicectomy, and was discharged with oral analgesia 3 days later. A specimen histology revealed

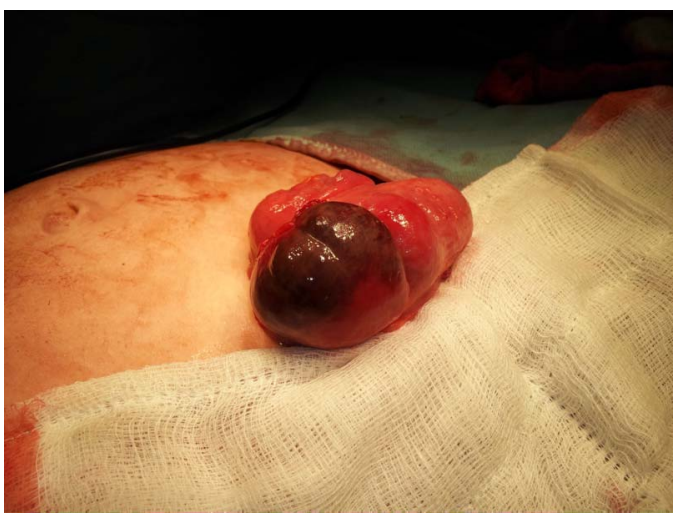

Figure 1 Inflamed caecal diverticula presenting as acute appendicitis (appendix not visible). inflammation of a caecal diverticulum and normal appendix (figure 1).

Caecal diverticula are thought to be congenital in origin. Other contributory factors include decreased fibre intake and lack of exercise-factors absent in this lady. ${ }^{2}$

Conservative management is only applicable if a strong diagnosis of right-sided diverticulitis is made through radiological investigations. Otherwise surgical management should be undertaken ranging from diverticulectomy, ileocaecal resection or right hemicolectomy. ${ }^{3}$

\section{Learning points}

- Consider caecal diverticulitis in patients presenting with right iliac fossa pain.

- Radiological investigations such as ultrasound, $\mathrm{CT}$ and MRI can be useful in determining caecal diverticulitis.

- The surgical management should be tailored to the individual patient depending on their clinical picture, discovery on radiological investigations and during exploration in the operating theatre-sometimes a simple excision compared with radical hemicolectomy is enough. Furthermore, this lady could have had a laparoscopic procedure. This has the advantage of improved diagnostic capability, reduced pain as a result of smaller incisions, shorter recovery time and shorter hospital stay.

Competing interests None.

Patient consent Obtained.

Provenance and peer review Not commissioned; externally peer reviewed.

\section{REFERENCES}

1 Radhi JM, Ramsay JM, Boutross-Tadross 0. Diverticular disease of the right colon. BMC Res Notes 2011:4:383.

2 Abogunrin FA, Arya N, Somerville JE. Solitary caecal diverticulitisa rare cause of right iliac fossa pain. U/ster Med J 2005;74:132-3.

3 Griffiths EA, Date RS. Acute presentation of a solitary caecal diverticulum: a case report. J Med Case Rep 2007;1:129.
To cite: Reddy R, Maitra I, Turner P. BMJ Case Rep Published online: [please include Day Month Year] doi:10.1136/bcr-2013010228 
Copyright 2013 BMJ Publishing Group. All rights reserved. For permission to reuse any of this content visit http://group.bmj.com/group/rights-licensing/permissions.

BMJ Case Report Fellows may re-use this article for personal use and teaching without any further permission.

Become a Fellow of BMJ Case Reports today and you can:

- Submit as many cases as you like

- Enjoy fast sympathetic peer review and rapid publication of accepted articles

- Access all the published articles

- Re-use any of the published material for personal use and teaching without further permission

For information on Institutional Fellowships contact consortiasales@bmjgroup.com

Visit casereports.bmj.com for more articles like this and to become a Fellow 